\title{
New Zealand
}

Indiana University Lilly Family School of Philanthropy

Country Overview

\begin{tabular}{|l|l|}
\hline Population (2018) & $4,841,000$ \\
\hline GNI Per Capita (2018) & $\$ 40,356$ \\
\hline Country Classification by Income Level (2018) & High-income \\
\hline Number of Registered Philanthropic Organizations (2018) & 27,428 \\
\hline Philanthropic Environment Country Overall Score (2018) & 4.33 \\
\hline $\begin{array}{l}\text { Philanthropic Environment Cross-Border Flows Score } \\
(2018)\end{array}$ & 4.10 \\
\hline
\end{tabular}

Data: Population, GNI Per Capita and Country Classification by Income Level: World Bank, www.worldbank.org

Number of Registered Philanthropic Organizations: Global Philanthropy Environment Index: Oceania,

globalindices.iupui.edu

Philanthropic Environment Country Overall Score and Cross-Border Flows Score: Indiana University Lilly Family

School of Philanthropy, 2018 Global Philanthropy Environment Index. globalindices.iupui.edu

Cross-Border Resource Flows, 2018 (in millions of inflation-adjusted 2018 US dollars)

\begin{tabular}{|c|c|c|c|c|}
\hline $\begin{array}{c}\text { Total } \\
\text { Resource Flows }\end{array}$ & Philanthropy & $\begin{array}{c}\text { Official } \\
\text { Development } \\
\text { Assistance (ODA) }\end{array}$ & Remittances & $\begin{array}{c}\text { Private Capital } \\
\text { Investment }\end{array}$ \\
\hline$\$ 3,116.61$ & $\$ 93.83$ & $\$ 556.03$ & $\$ 2,407.98$ & $\$ 58.77$ \\
\hline \multicolumn{2}{|c|}{ Quality of Data on Philanthropic Outflows } & \multicolumn{2}{|c}{} \\
\hline
\end{tabular}

Data: Indiana University Lilly Family School of Philanthropy, 2020 Global Philanthropy Tracker 


\section{Summary of cross-border philanthropy}

Data and information for cross-border giving in New Zealand can be found in the $2017 \mathrm{New}$ Zealand Cause Report published by JBWere New Zealand. The report used nonprofit organization financial account information from sources including the Statistics New Zealand Non-profit Institutions Satellite Accounts and the Charities Services annual returns data.

Furthermore, Giving New Zealand published by Philanthropy New Zealand also provides valuable information on individual and foundation cross-border giving in New Zealand, using variety of data sources such as the Charities Register, annual returns to the Inland Revenue Department, and their own primary data collected through a survey of grantmakers.

\section{SENDING CROSS-BORDER CHARITABLE DONATIONS}

There are no restrictions on sending cross-border charitable donations from New Zealand (Indiana University Lilly Family School of Philanthropy, 2018). However, philanthropic organizations receiving income that is intended for use in projects outside New Zealand are not eligible for the exemption from income tax, unlike domestic-focused organizations.

\section{RECEIVING CROSS-BORDER CHARITABLE DONATIONS}

Individuals and private philanthropic organizations can freely receive cross-border donations (Indiana University Lilly Family School of Philanthropy, 2018). However, the Goods and Service Tax is levied on imported gifts worth more than USD 120. Bequests are exempt from this duty tax.

\section{ESTIMATED CROSS-BORDER GIVING}

Organizations that specialize in international activities rely on philanthropy more than any other sector, as philanthropy represents about 70 percent of the sector's income compared to an average 15 percent of income, overall. In 2015, New Zealand's aggregate cross-border giving was approximately NZD 130 million (McLeod, 2017). This total represents donations and bequests to international causes, a category which includes activities such as cultural exchange programs, disaster relief organizations, human rights organizations, and development assistance organizations.

Looking at individual and foundation giving across borders, individual cross-border giving represents a large fraction of aggregate cross-border giving, which amounted to NZD 119.4 million in 2014 (Cox et al., 2014). Cross-border giving by foundations was NZD 5.276 million in 2014 (Cox et al., 2014).

\section{ESTIMATED CROSS-BORDER VOLUNTEERING}

In 2014, volunteers provided one million hours of service for international aid. Based on the New Zealand minimum wage at the time, the economic value of these volunteer hours was at least NZD 13.75 million (Cox et al., 2014). 


\section{CROSS-BORDER GIVING BY CHARITABLE CAUSES}

There are no specific data on the distribution of cross-border giving to charitable causes.

However, the "international causes" sector in New Zealand philanthropy encompasses themes including cultural exchange programs, disaster relief organizations, human rights organizations, and development assistance organizations.

\section{KEY DEVELOPMENTS AND TRENDS IN CROSS-BORDER GIVING}

The number of small donors is falling in the New Zealand philanthropic sector, but other donors give larger amounts more often. Despite fewer small donors, the increased number of larger donors enables different philanthropic strategies to take hold that could mean a greater impact for overseas projects: in particular, the increased value placed on projects of longer duration with higher budgets suggests potential to reach a greater number of people. The trend of collaborative philanthropy facilitates such projects by pooling greater amounts of funds, expanding the potential of overseas projects (Cooney, 2019).

\section{References}

Cooney, M. (2019, October 22). We delve into the landscape of philanthropy in NZ to explore this fascinating and ever-changing space. The Denizen. https://www.thedenizen.co.nz/culture/philanthropy/

Cox, M., Stokes, F., \& Dixon, H. (2014). Giving New Zealand: Philanthropic Funding 2014.

Indiana University Lilly Family School of Philanthropy. (2018). Global Philanthropy Environment Index: New Zealand. https://globalindices.iupui.edu/

McLeod, J. (2017). The New Zealand Cause Report: Shape of the Charity Sector.

\section{Do you have information to add to this profile?}

We greatly appreciate the contributions of researchers, scholars, and leaders around the world to the study of cross-border philanthropy. If you know of any additional information or newly available data that could be included in future editions, please send us an update at indices@iupui.edu. 